\title{
VIDEOVIGILANCIA EN LAS AULAS UNIVERSITARIAS Y PROTECCIÓN DE LA VIDA PRIVADA. CONSIDERACIONES SOBRE LA STEDH DE 28 DE NOVIEMBRE DE 2017 (CASO ANTOVIĆ)
}

Video Surveillance in university lecture halls and protection of private life. Considerations on the ECHR Judgment 28th November 2017 (case Antović)

\author{
RAQUEL EVANGELIO LLORCA \\ Universidad de Alicante \\ r.evangelio@ua.es
}

Cómo citar/Citation

Evangelio Llorca, R. (2018).

Videovigilancia en las aulas universitarias y protección de la vida privada. Consideraciones sobre la STEDH de 28 de noviembre de 2017 (caso Antović). Derecho Privado y Constitución, 33, 79-116. doi: https://doi.org/10.18042/cepc/dpc.33.03

(Recepción: 30/06/2018; aceptación tras revisión: 24/09/2018; publicación: 28/11/2018)

\section{Resumen}

Al hilo de la reciente Sentencia del Tribunal Europeo de Derechos Humanos de 28 de noviembre de 2017 (Antović y Mirković c. Montenegro), se analizan en este trabajo dos cuestiones principales. La primera es si la instalación y el uso de cámaras de videovigilancia en las aulas de una universidad suponen una injerencia en el derecho a la vida privada de los profesores (y los alumnos) a efectos del art. 8 del Convenio Europeo de Derechos Humanos. En cuanto a la segunda, que parte de una contestación afirmativa a la anterior, se refiere a en qué casos dicha injerencia no constituye, 
sin embargo, una violación del citado precepto por concurrir las circunstancias legitimadoras previstas en él.

\section{Palabras clave}

Convenio Europeo de Derechos Humanos; Tribunal Europeo de Derechos Humanos; derecho al respeto de la vida privada; protección de datos personales; videovigilancia en aulas universitarias.

\section{Abstract}

This paper will focus on two main issues arising from the recent European Court of Human Rights Judgement of 28th November 2017 (Antović y Mirkovićv. Montenegro). The former refers to whether the installation and use of video surveillance equipment in university auditoriums constitutes an interference with teachers' (and students') right to respect of private life within the meaning of Article 8 of the European Convention on Human Rights. Regarding the latter, which implies an affirmative answer to the previous one, analyses the cases in which that intromission does not violate the forementioned article because certain legal requirements referred to in it are fulfilled.

\section{Keywords}

European Convention on Human Rights; European Court of Human Rights; right to respect of private life; personal data protection; video surveillance in university classrooms. 


\section{SUMARIO}

I. INTRODUCCIÓN. II. LA STEDH DE 28 DE NOVIEMBRE DE 2017 (CASO ANTOVIĆ). III. EL ART. 8 DEL CEDH Y SU APLICACIÓN POR EL TRIBUNAL DE ESTRASBURGO. IV. LA DELIMITACIÓN DEL DERECHO AL RESPETO A LA VIDA PRIVADA: 1. El concepto de vida privada. La «vida privada social» y la «expectativa razonable de intimidad». 2. Vida privada y aulas universitarias: 2.1. Las aulas universitarias como espacios semiprivados. 2.2. La expectativa razonable de intimidad de los profesores (y los alumnos) en las aulas universitarias. 3. El derecho a la protección de datos personales como contenido del derecho a la vida privada del art. $8 \mathrm{CEDH}$. La imagen como dato protegido. V. LA INTROMISIÓN EN LA VIDA PRIVADA Y LOS REQUISITOS PARA JUSTIFICARLA: 1. La conformidad con la ley. La base jurídica legitimadora de la videovigilancia en las aulas universitarias. 2. Los fines legítimos. 3. La necesidad de la interferencia en una sociedad democrática. El principio de proporcionalidad. BIBLIOGRAFíA

\section{INTRODUCCIÓN}

Una reciente sentencia del Tribunal Europeo de Derechos Humanos (TEDH), de 28 de noviembre de 2017 (Antović y Mirković c. Montenegro), ha puesto sobre el tapete la cuestión de si la instalación y el uso de videocámaras en las aulas universitarias viola el derecho a la vida privada de los profesores previsto en el art. 8 del Convenio Europeo de Derechos Humanos; así como la de si, en caso de que efectivamente tal medida implique una intromisión en el mencionado derecho, es no obstante conforme con el citado precepto por concurrir todas las circunstancias que, según el mismo, legitiman la injerencia.

Se trata de dos interrogantes que no permiten una respuesta clara, tal y como se demuestra por la existencia de dos votos particulares a la misma, uno concurrente suscrito por dos de los siete magistrados del tribunal, y otro disidente sostenido por tres de ellos.

Pues bien, el primer aspecto requiere analizar el alcance del derecho a la vida privada del art. 8 del Convenio Europeo de Derechos Humanos $(\mathrm{CEDH})$, atendiendo a la interpretación que del mismo lleva a cabo el Tribunal de Estrasburgo; lo cual pasa por tener en cuenta conceptos por este acuñados como el de «vida privada social» $\mathrm{y}$ «expectativa razonable de intimidad», así 
como por distinguir entre la privacidad y la protección de los datos personales como componentes ambos del derecho a la vida privada, o discernir la naturaleza pública o privada (o ni una cosa ni la otra) de las aulas universitarias en las que se desarrollan las clases.

En cuanto a la segunda cuestión, exige el estudio de las tres circunstancias que, de acuerdo con el art. $8 \mathrm{CEDH}$, deben darse cumulativamente para que una intromisión en la vida privada de las personas sea, no obstante, legítima. Salvo la primera (conformidad con la ley), se trata de requisitos difusos, que permiten un margen amplio de apreciación y, por lo tanto, impiden llevar a cabo afirmaciones rotundas.

De todo ello me ocuparé en las páginas que siguen, en las que, continuando el hilo conductor de la sentencia comentada y la regulación prevista en el CEDH, me referiré también al nuevo Reglamento Europeo de Protección de Datos y a la normativa española al respecto, así como a la posición de los tribunales españoles y de la Agencia Española de Protección de Datos.

\section{LA STEDH DE 28 DE NOVIEMBRE DE 2017 (CASO ANTOVIĆ)}

El origen del litigio se remonta a 2011, cuando el decano de la Facultad de Matemáticas de la Universidad de Montenegro informó a los profesores, primero verbalmente durante una junta de facultad, y después por escrito mediante una resolución, de que se habían instalado siete cámaras de videovigilancia en los anfiteatros en los que se impartían las clases y otra más delante del despacho decanal. Según se señalaba, el propósito de la medida era garantizar la seguridad de los bienes y de las personas y vigilar la enseñanza. Se indicaba también que el acceso a los datos recogidos estaba protegido por códigos que solo el decano conocía, así como que los datos estarían almacenados durante un año.

Dos profesores presentaron una queja ante la Agencia de Protección de Datos montenegrina por haberse instalado las cámaras y captado sus datos sin su consentimiento. Los docentes alegaban, con base en la Ley de Protección de Datos Personales (LPDP), que las aulas se cerraban tanto antes como después de las clases, que los únicos bienes que había en ellas eran pupitres y sillas fijos y una pizarra, que no conocían ninguna razón para temer por la seguridad de personas o bienes y que, en todo caso, había otros métodos para proteger a las personas y el patrimonio y para controlar la enseñanza. Por todo ello solicitaban que las cámaras fueran retiradas y que se borraran los datos almacenados.

A raíz de la queja, dos inspectores de la agencia visitaron la facultad y emitieron un informe en el que afirmaron que la videovigilancia instalada 
era acorde con la LPDP. Dicho informe fue recurrido por los profesores, y el recurso fue estimado por la Agencia de Protección de Datos montenegrina, la cual ordenó la retirada de las cámaras en un plazo de quince días por incumplimiento de varias normas de la LPDP. Concretamente, se consideró que no habían quedado justificados los motivos recogidos en el art. 36 para la introducción de la videovigilancia, ya que, por un lado, no se habían aportado pruebas suficientes del riesgo para las personas y los bienes en los auditorios, y por otro, entre los mencionados motivos no se incluía el control de las clases.

Notificada la decisión de la Agencia a la Facultad de Matemáticas, esta procedió a la retirada de las cámaras, así como al borrado de los datos almacenados.

Terminado el procedimiento administrativo, los profesores iniciaron un proceso judicial contra la universidad, la Agencia de Protección de Datos y el Estado de Montenegro en reclamación de una indemnización de daños como consecuencia de la violación de su derecho a la vida privada reconocido por la LPDP y el art. 8 CEDH.

El tribunal de primera instancia desestimó la demanda sobre la base de que la universidad es una institución pública en la que se desarrollan actividades de interés público, entre ellas la enseñanza, y que, por tanto, la videovigilancia de las aulas en cuanto que lugares públicos no violaba el derecho a la vida privada de los demandantes. Las aulas —añadía la sentencia - son lugares de trabajo, al igual que una sala de audiencias o un parlamento, donde los profesores nunca están solos, y por tanto no pueden invocar ningún derecho a la privacidad que pudiera ser violado, ni los datos recogidos y almacenados podían considerarse de carácter personal. En este sentido, la sentencia afirmaba que la videovigilancia de acciones que tienen lugar en público no constituye una interferencia en la vida privada de una persona cuando simplemente se graba lo que otros podrían ver si estuvieran en el mismo lugar al mismo tiempo. Tal interferencia se daría, en su caso, si se hiciera pública la grabación realizada.

Los demandantes recurrieron, insistiendo en sus argumentos, pero el recurso fue desestimado por las mismas razones por las que se rechazó la demanda.

Así las cosas, los profesores decidieron acudir al TEDH, fundando su reclamación en el art. 8 del CEDH. De acuerdo con los actores, la universidad había violado su derecho a la vida privada porque la videovigilancia había sido ilegal, no perseguía ningún fin legítimo y no era necesaria en una sociedad democrática; además, los demandantes no tenían ningún control sobre los datos recogidos y almacenados por el decano.

Frente a ello, el Gobierno de Montenegro se defendió con argumentos de fondo y de forma. Respecto a los primeros, usó, en gran parte, los de la 
sentencia de primera instancia, a los que añadió que la videovigilancia, sin perjuicio de ciertos fallos administrativos, había sido legal, había perseguido un fin legítimo y había sido necesaria en una sociedad democrática.

En cuanto al fin legítimo, que a su juicio no podría haberse conseguido de un modo menos invasivo, había sido la prevención y la investigación de incidentes relacionados con la seguridad. No hubo referencia del Gobierno, en cambio, al propósito adicional de control de la enseñanza que había sido denunciado por los profesores demandantes.

El Gobierno sostenía, por otra parte, que las personas afectadas por el sistema de vigilancia, incluidos los demandantes, habían sido debidamente informadas; que los datos recogidos y almacenados, a los que solo el decano de la facultad había tenido acceso, no se habían utilizado de forma incorrecta y habían sido borrados automáticamente al cabo de treinta días. Asimismo, afirmaba que las cámaras habían captado imágenes de baja resolución, que no tenían zoom y que su ubicación se había hecho de conformidad con un análisis del riesgo, pero también con la protección de datos.

Respecto a la forma, el Gobierno demandado opuso que los actores no habían agotado la vía nacional, ya que no habían recurrido ante el Tribunal Constitucional montenegrino.

El Tribunal de Estrasburgo estimó las pretensiones de los demandantes, declarando que el art. $8 \mathrm{CEDH}$ había sido violado, por los motivos que a lo largo de este trabajo se irán detallando. Por esta razón, de acuerdo con el art. $40 \mathrm{CEDH}$, concedió a cada uno de los demandantes los 1.000 euros que habían solicitado en concepto de daño moral; y condenó, además, a los demandados, al pago de las costas solicitadas por los demandantes (1.312,50 euros por las costas generadas por la reclamación ante los tribunales nacionales y 357 euros por las costas relativas a la reclamación ante el TEDH).

La sentencia fue objeto de un voto particular concurrente de dos magistrados y de uno discrepante de otros tres.

\section{EL ART. 8 DEL CEDH Y SU APLICACIÓN POR EL TRIBUNAL DE ESTRASBURGO}

De acuerdo con el art. 8 CEDH:

1. Toda persona tiene derecho al respeto de su vida privada y familiar, de su domicilio y de su correspondencia. 2. No podrá haber injerencia de la autoridad pública en el ejercicio de este derecho, sino en tanto en cuanto esta injerencia esté prevista por la ley y constituya una medida que, en una sociedad democrática, sea necesaria para la seguridad nacional, la seguridad pública, el bienestar económico del país, la 
defensa del orden y la prevención del delito, la protección de la salud o de la moral, o la protección de los derechos y las libertades de los demás ${ }^{1}$.

En el primer apartado de la norma se indica cuál es el derecho protegido, a saber, el respeto a la vida privada y familiar, al domicilio y a la correspondencia. Se ha dicho que es «el menos definido y el más indisciplinado de los derechos previstos en el Convenio» - Juez S. Burnton en S. de la Corte Suprema de Inglaterra y Gales (Tribunal Administrativo) de 16 de noviembre de 2006, Wright c. Secretaría de Estado para la Salud (2006) EWHC 2886 (Admin.), párr. 66 - Y es que, como destacan Harris et al. (2014: 520), el art. 8 $\mathrm{CEDH}$ impone a los Estados la obligación de respetar un abanico de intereses personales indefinidos que abarcan distintos aspectos interrelacionados y superpuestos. Dado que ninguno de esos intereses se define en el Convenio, su concepto y alcance han de interpretarse. A este respecto, el TEDH se decanta por una interpretación amplia, como después se verá, lo que, si bien tiene sus riesgos, presenta también la ventaja de facilitar la adecuación del precepto al desarrollo social y tecnológico.

En cuanto al segundo apartado, aclara que el derecho previsto en el anterior no es absoluto, sino que, en determinadas circunstancias que la propia norma recoge, puede haber injerencias por parte de las autoridades públicas (Kilkelly, 2001: 6).

La estructura de la norma lleva a que, para determinar si ha habido una infracción del art. $8 \mathrm{CEDH}$, el Tribunal de Estrasburgo debe seguir dos pasos: primero, discernir si dicho precepto es aplicable, es decir, si los hechos enjuiciados afectan a la vida privada o familiar, al hogar o a la correspondencia del sujeto que presenta su queja ante él; y segundo (solo si su conclusión es afirmativa), establecer si la norma ha sido infringida.

Este precepto procede de la Declaración Universal de Derechos Humanos (DUDH) adoptada el 10 de diciembre de 1948 por la Asamblea General de Naciones Unidas. $\mathrm{El}$ art. 8.1 del Convenio deriva del art. 12 de la Declaración Universal, mientras que el art. 8.2 del Convenio, por su parte, tiene su antecedente en el art. 29.2 (Schabas, 2015: 359). La Carta de Derechos Fundamentales de la UE, por su parte, reproduce casi literalmente el art. 8.1 CEDH, con la única diferencia de que, para acomodarse al progreso tecnológico, se sustituye la referencia a "correspondencia» por "comunicaciones» (Grabenwarter, 2014: 185).

En el ámbito internacional, aparte de la ya mencionada DUDH, el derecho a la intimidad se consagra en el art. 17 del Pacto Internacional sobre Derechos Civiles y Políticos de 1966, así como en el art. 11.2 de la Convención Americana de Derechos Humanos de 1969. 
Así las cosas, a continuación se analizarán ambas fases por separado, refiriéndolas específicamente a la sentencia Antović.

\section{LA DELIMITACIÓN DEL DERECHO AL RESPETO A LA VIDA PRIVADA}

Como se ha dicho, la primera fase del análisis que debe llevar a cabo el TEDH es la de valorar si el art. $8 \mathrm{CEDH}$ resulta aplicable, esto es, si el supuesto planteado afecta a la vida privada o familiar del demandante. A nuestros efectos, ello pasa por determinar cuál es el alcance del derecho a la vida privada y si puede existir vida privada en las aulas de una universidad.

\section{EL CONCEPTO DE VIDA PRIVADA. LA «VIDA PRIVADA SOCIAL» Y LA «EXPECTATIVA RAZONABLE DE INTIMIDAD»}

Haciéndose eco de sentencias anteriores, el TEDH reitera en este fallo su opinión sobre la imposibilidad de definir el concepto de «vida privada» del art. $8 \mathrm{CEDH}$, así como la defensa de una interpretación amplia de dicha expresión ${ }^{2}$, en la que, caso a caso, el Tribunal identifica las situaciones que caen bajo su ámbito (Roagna, 2012: 123).

En lo que aquí interesa, el derecho al respeto de la vida privada y familiar alberga el derecho a una "vida privada social», entendido como la posibilidad de la persona de desarrollar su identidad social mediante sus relaciones con los

2 Esta idea es una constante en la jurisprudencia de Estrasburgo. En este sentido, cabe citar, sin ánimo de exhaustividad, las SSTEDH de 16 de diciembre de 1992, Niemietz, párr. 29; 25 de septiembre de 2001, P. G. y J. H., párr. 56; 28 de enero de 2003, Peck, párr. 57; 17 de julio de 2003, Perry, párr. 36; 24 de julio de 2003, Smirnova, párr. 95; 12 de junio de 2014, Fernández Martínez, y 5 de septiembre de 2017, Barbulescu II, párr. 70, varias de ellas citadas por la que ahora nos ocupa, y la más reciente de 9 de enero de 2018, López Ribalda y otros, párr. 54.

3 Para una exposición detallada de los diferentes aspectos que el TEDH incluye en el ámbito de la vida privada y familiar, véase Harris et al., 2014: 536 y ss. Como apunta Rebollo Delgado (s. f.: 97), este modo de proceder del Tribunal de Estrasburgo es deliberado y se basa en el carácter expansivo y mudable que atribuye al derecho a la vida privada, en la medida en que ha de ser el resultado de unas aspiraciones y necesidades sociales, y además, varía con el paso del tiempo y de unos lugares a otros, incluso dentro de la misma Europa. 
demás ${ }^{4}$. Estas relaciones pueden incluir las laborales o profesionales y las desarrolladas en un contexto público, en las que no siempre es posible distinguir con claridad qué actividades del individuo forman parte de su vida profesional o empresarial y cuáles no. Existe, en definitiva, una zona de interacción de una persona con otras, incluso en un contexto público, que puede caer en el ámbito de la «vida privada», de la que forma parte la vida profesionals.

Es obligado plantear, si bien de forma breve, el paralelismo entre el derecho a la vida privada del art. $8 \mathrm{CEDH}$ y el derecho a la intimidad del art. 18 CE. Aunque pudiera parecer que coinciden, en realidad el primero, según la interpretación que lleva a cabo del mismo el Tribunal de Estrasburgo, es más amplio que el segundo ${ }^{6}$, que, según el TC, «implica la existencia de un ámbito propio y reservado frente a la acción y el conocimiento de los demás, necesario, según las pautas de nuestra cultura, para mantener una calidad mínima de vida humana ${ }^{7}$. Hay quien afirma que la intimidad vendría a ser un primer

4 Se apunta la Decisión de 7 de mayo de 1976, X, en la que se inadmitió la demanda interpuesta por inaplicabilidad del art. $8 \mathrm{CEDH}$ a las relaciones entre un ser humano y un perro, como la primera vez en que el Tribunal de Estrasburgo afirmó que el derecho al respeto de la vida privada «no se limita a la intimidad, sino que comprende el derecho a entablar y desarrollar relaciones con otros seres humanos, especialmente en el ámbito emocional, para el desarrollo y plenitud de la propia personalidad» (Harris et al., 2014: 525). Esta idea se confirmó en la STEDH de 16 de diciembre de 1992, Niemietz, párr. 29, en la que se declaró que el derecho a la vida privada no puede reducirse a un "círculo íntimo» en el que el individuo puede vivir su vida personal como elija y que excluye por completo a todos quienes no forman parte de ese núcleo íntimo. En igual sentido, la reciente STEDH de 5 de septiembre de 2017, Barbulescu II, párr. 70, y la que ahora se comenta.

5 En la misma línea, SSTEDH de 16 de diciembre de 1992, Niemietz, párr. 29, que fue el primer fallo en el que el TEDH admitió que la vida profesional entra en el concepto de vida privada; 25 de septiembre de 2001, P. G. y J. H., párr. 56; 28 de enero de 2003, Peck, párr. 57; 15 de mayo de 2012, Fernández Martínez, párr. 57; 12 de junio de 2016, Barbulescu I, párr. 54, y 5 de septiembre de 2017 (Gran Sala), Barbulescu II, párr. 71.

6 Así lo afirman también Ollero Tassada (2015: 172) y De Salas (2017: 96). Para el autor citado en primer lugar, las resoluciones de Estrasburgo llevan trazas de identificar la privacidad con lo que el art. 10.1 CE caracteriza como «libre desarrollo de la personalidad».

7 SSTC 110/1984, de 26 de noviembre (RTC 1984/110); 170/1987, de 30 de octubre (RJC 1987/170); 231/1988, de 2 de diciembre (RJC 1988/231); 57/1994, de 28 de febrero (RJC 1994/57); 207/1996, de 16 de diciembre (RJC 1996/207); 202/1999, de 8 de noviembre (RJC 1999/202); 186/2000, de 10 de julio (RJC 2000/186); 196/2004, de 15 de noviembre (RJC 2004/196); 241/2012, de 17 de diciembre (RJC 
círculo concéntrico de la vida privada, rodeado por un segundo, constituido por aquellos aspectos que el individuo comparte en un ámbito un poco más genérico, pero en sí reducido (familia, amigos), y este, a su vez, por un tercero, compuesto por lo que la sociedad puede conocer del individuo, o lo que este quiere que conozcan de él en su relación social (Rebollo Delgado, s. f.: 99). Otros estiman que es una de las manifestaciones de la vida privada, junto con los demás derechos recogidos en el art. 18 CE (De las Heras Muñoz, 2013: 115).

Este alcance más restringido que se atribuye al derecho a la intimidad del art. $18 \mathrm{CE}$ en relación con el derecho a la vida privada del art. $8 \mathrm{CEDH}$ no puede conducir, sin embargo, a excluir la posibilidad de intimidad en el ámbito laboral. De hecho, aunque en un primer momento tanto los tribunales del orden laboral como el TC español concebían el centro de trabajo como un lugar público y entendían que en el ámbito personal y familiar no se podían incluir hechos referidos a las relaciones sociales y profesionales que rodeaban a la actividad laboral (STC 142/1993, de 22 de abril), esa perspectiva fue superada a partir del año 2000, y desde entonces, los conflictos derivados de la instalación de sistemas de videovigilancia desde el punto de vista de la vulneración del derecho constitucional a la intimidad ( $\mathrm{y}$ a la propia imagen ${ }^{8}$ ).

Por otro lado, a la hora de determinar el ámbito de la vida privada, el tribunal recuerda que un factor importante es el de la «expectativa razonable de intimidad». Este concepto fue acuñado por primera vez por la jurisprudencia estadounidense en el caso Katz de $1967^{\circ}$ (Winn, 2008: 1) y fue acogido por el TEDH en el caso Halford (STEDH de 25 de junio de 1997), y más

2012/241), y 170/2013, de 7 de octubre (RJC 2013/170). Aunque con referencia limitada al derecho a la intimidad familiar del art. $18 \mathrm{CE}$ y al derecho a la vida privada familiar del art. $8 \mathrm{CEDH}$, el TC ha distinguido claramente el alcance de ambos, afirmando la mayor amplitud del segundo (STC 186/2013, de 4 de noviembre [BOE-A-2013-12724]).

8 En este sentido, Gude Fernández, A. (2014: 5-7). No comparto, por tanto, la opinión de Blázquez Aguado (2017: 1) quien, siguiendo a Desdentado Bonete y Muñoz Ruiz (2012: 10), afirma que, aunque el centro de trabajo no es un lugar donde se ejerza directamente el derecho a la intimidad, puesto que el trabajo no es un acto íntimo sino social, pueden producirse situaciones de lesividad del derecho. Personalmente me sitúo más en la línea del Grupo de Trabajo sobre el Artículo 29 (GT29), creado por el art. 29 Dir. 95/46/CE, cuando afirma que «[1] os trabajadores no dejan su derecho a la vida privada y a la protección de datos cada mañana a la puerta de su lugar de trabajo. Esperan legítimamente encontrar allí un grado de privacidad, ya que en él desarrollan una parte importante de sus relaciones con los demás» (2002: 4).

9 Sobre esta sentencia puede verse Winn (2008) y Schneider (2009). 
recientemente, por los tribunales españoles, en la STS de 26 de septiembre de 2007 (García y Pastor, 2016: 2). Con posterioridad a la sentencia Halford, son varias las ocasiones - incluyendo el caso Antović- en que el Tribunal de Estrasburgo ha manejado el elemento de la «expectativa razonable de intimidad» afirmando que es un factor relevante, aunque no necesariamente determinante ${ }^{10}$.

\section{VIDA PRIVADA Y AULAS UNIVERSITARIAS}

Con base en las anteriores consideraciones, en la sentencia que se comenta se afirma que las aulas universitarias son los lugares de trabajo de los profesores, en los que no solo enseñan a los estudiantes, sino que interactúan con ellos, y por tanto desarrollan relaciones y construyen su identidad social. A este respecto el Tribunal de Estrasburgo recuerda que en el lugar de trabajo existe vida privada social, que si bien puede limitarse por el empresario cuando ello sea necesario, en ningún caso puede suprimirse por completo ${ }^{11}$; de modo que la videovigilancia de un empleado en su puesto de trabajo es una intromisión en su vida privada y, por tanto, una interferencia a los efectos del art. $8 \mathrm{CEDH}$. Por consiguiente, concluye que este precepto es aplicable.

En el voto particular concurrente, se afirma que la decisión no debería haber puesto el acento en la circunstancia de que las aulas son los lugares de trabajo de los profesores y, por tanto, en la consideración de los hechos como una interferencia del empleador en la vida privada de sus empleados, sino en la naturaleza de la actividad realizada bajo vigilancia. Según los magistrados que firmaron este voto particular, las aulas universitarias no son lugares públicos ni privados; son los lugares donde los profesores se reúnen e interactúan con sus alumnos, siendo esta interacción de naturaleza particular, no puramente social. En ella, el profesor tiene una razonable expectativa de privacidad, basada en la libertad académica que ampara la actividad docente y de aprendizaje, y entendida en el sentido de que el profesor puede razonablemente esperar que lo que está ocurriendo durante su clase solo pueda ser seguido por quienes tienen derecho a asistir y quienes efectivamente asisten (con excepciones, como la grabación de la clase para fines educativos, por ejemplo para permitir su uso

10 En esta línea, SSTEDH de 25 de septiembre de 2001, P. G. y J. H., párr. 57; 17 de julio de 2003, Perry, párr. 37; 12 de enero de 2016, Barbulescu I, y 9 de enero de 2018, López Ribalda y otros, párr. 57.

11 En España, el TC ha declarado que «[1]a celebración de un contrato de trabajo no implica en modo alguno la privación para una de las partes, el trabajador, de los derechos que la Constitución le reconoce como ciudadano» (STC 88/1985, de 19 de julio, ECLI:ES:TC:1985:88). 
por alumnos que no pueden asistir a clase); sin que haya, por tanto, «atención no deseada» por parte de terceros. Y ello porque en el aula el profesor puede permitirse actuar de un modo en el que quizá nunca se comportaría fuera de ella. Con base en todo lo anterior, entendieron aplicable el art. $8 \mathrm{CEDH}$.

Por su parte, los magistrados que suscribieron el voto particular disidente sostuvieron que la sentencia «expande» el alcance del derecho a la vida privada del art. $8 \mathrm{CEDH}$ sin base suficiente ni en la jurisprudencia del propio Tribunal ni en la ley. En este sentido, citaron decisiones anteriores del TEDH en las que se afirma que el concepto de "vida privada» no puede aplicarse a sitios que son libremente accesibles para el público y que se usan para actividades no relacionadas con la esfera privada de las personas; así como que el uso de cámaras de seguridad en lugares o calles públicos no es contrario al art. $8 \mathrm{CEDH}$, sin perjuicio de que la grabación, el almacenaje sistemático o permanente y el uso de datos puede interferir con la vida privada, aun cuando se hayan grabado en lugares públicos. Así pues, según estos magistrados, de la jurisprudencia anterior del Tribunal se desprende que la videovigilancia no constituye, en sí misma, una interferencia con las vidas privadas de las personas vigiladas, sino que la existencia o no de dicha interferencia depende de diversos factores, tales como el lugar en que se instalan las cámaras, la naturaleza de las actividades controladas, si la videovigilancia está dirigida y es sistemática, si las personas vigiladas tenían una expectativa razonable de privacidad, si habían sido previamente informadas, o si la información es almacenada, procesada y utilizada. Pues bien, de acuerdo con ello, se sostiene que en el caso concreto había que tener en cuenta: a) que las aulas universitarias son espacios semipúblicos, en los que el profesor lleva a cabo una actividad profesional; b) que los profesores demandantes tenían una expectativa razonable de intimidad "muy limitada», ya que habían sido previamente notificados de la instalación de cámaras en las aulas; c) que la videovigilancia era remota, que no había grabación de voz ni por tanto de la enseñanza o los debates, que las imágenes eran borrosas y que no se podía reconocer fácilmente a las personas, y d) que las grabaciones solo estaban disponibles para el decano y que se borraban automáticamente al cabo de treinta días, y que los datos almacenados no eran utilizados. Por consiguiente, a su entender no había interferencia con la vida privada de los profesores.

Así las cosas, procede determinar la naturaleza pública o privada de las aulas universitarias y si los profesores demandantes tenían o no una expectativa razonable de intimidad en ellas.

\subsection{Las aulas universitarias como espacios semiprivados}

La doctrina distingue cuatro tipos de espacios: públicos, privados, semipúblicos y semiprivados. 
Los espacios públicos (parques, calles, plazas) suelen determinarse, según González Galán (2008: 77-78 y 80-81), mediante tres características esenciales: titularidad pública, plurifuncionalidad y accesibilidad, cuyo elemento determinante es la libertad de entrada, frecuentemente acompañada de la continuidad en el acceso y la gratuidad. Frente a ellos, los espacios privados (como una vivienda) se caracterizan por ser de titularidad privada, tener una accesibilidad restringida y destinarse a dotar al individuo de un lugar propio e íntimo en el que se desarrollan relaciones horizontales (familiares, de amistad).

Entre unos y otros existen los espacios semiprivados y los semipúblicos. Los primeros (asociaciones, oficinas, centros religiosos) son de titularidad privada, tienen una accesibilidad restringida a los miembros de un colectivo concreto (asociados, trabajadores), entre los que existen relaciones horizontales y pueden ser, aunque no es frecuente, plurifuncionales. Los espacios semipúblicos (bares, gimnasios, museos y bibliotecas, parques recreativos), por su parte, pueden ser de titularidad pública o privada, su accesibilidad suele estar limitada al pago de una entrada, aunque no necesariamente es así, y tienen una plurifuncionalidad escasa, ya que suelen ser espacios dedicados a una actividad concreta, cuya finalidad es dotar al ciudadano de una serie de servicios, y en los que priman las relaciones anónimas y de servicios (González Galán, 2008: 91).

Con base en lo anterior, las aulas universitarias podrían encajar en la categoría de espacios semipúblicos — como expresamente se afirma en el voto particular disidente de la sentencia que se comenta-; aunque también, por el tipo de relaciones que se desarrollan en ellas y por ser lugares de trabajo, podrían calificarse como espacios semiprivados ${ }^{12}$. En cualquier caso, lo que está claro es que constituyen un tertium genus entre los espacios públicos y los privados (o, como se sostiene en el voto particular concurrente, lugares «ni públicos ni privados»); y que esta naturaleza no es incompatible con la vida privada, que incluye, como afirma el Tribunal de Estrasburgo, la ya mencionada «vida privada social».

Por otra parte, interesa señalar que ni siquiera los espacios netamente públicos son incompatibles con sucesos privados. En efecto, como señala $\mathrm{Na}$ valpotro Ballesteros (2007: 5), la jurisprudencia del TEDH ha evolucionado de una posición inicialmente basada en la contraposición entre hecho privado y localización pública (caso $X$, de 12 de octubre de 2003), a otra que permite

12 Según la AEPD, esta es calificación correcta en sentido técnico jurídico, como indica, entre otras muchas resoluciones, el Auto del Tribunal Supremo (Sala de lo Civil) de 14 abril 2009 (Informe 0186/2017: 4). No obstante, yo no he podido encontrar la resolución citada ni ninguna otra en tal sentido. 
compatibilizar la condición de privado de un dato o suceso con su realización en un lugar público (así, en los casos Peck, de 28 de enero de 2003; Perry, de 17 de julio de 2003; y Von Hannover, de 24 de junio de 2004). En el caso Peck, por ejemplo — destaca el citado autor-, el Tribunal de Estrasburgo concluye que las imágenes del demandante grabadas por las cámaras eran de carácter privado, no obstante, se producían en un lugar público. Y ello atendiendo a que Mr. Peck estaba en una calle pública pero no para participar en ningún acontecimiento público y no era una figura pública, a que era de noche y a que el demandante estaba profundamente perturbado y en un estado de angustia (párr. 62). Sobre esta base —añado yo-, el Tribunal considera que, si bien la mera captación de las acciones de una persona en un lugar público no implica, de por sí, una injerencia en su vida privada, la grabación y el almacenaje sistemático y permanente de las imágenes captadas sí puede serlo, como sucedió en el caso en cuestión.

A esta jurisprudencia, precisamente, acude el voto particular disidente de la sentencia Antović para defender la no intromisión en la vida privada de los profesores demandantes.

Sin embargo, a mi entender la aplicación de esta doctrina jurisprudencial no impediría (en todo caso, reforzaría) la aplicabilidad del art. $8 \mathrm{CEDH}$ al caso enjuiciado, ya que las circunstancias son aquí diferentes. Por un lado, ya se ha visto que las aulas universitarias no son lugares públicos (como, por cierto, reconocen los propios magistrados disidentes) y tampoco se usan para actividades no relacionadas con la esfera privada de las personas, ya que en ellas se desarrolla la «vida privada social» a la que se refiere el TEDH.

\subsection{La expectativa razonable de intimidad de los profesores (y los alumnos) en las aulas universitarias}

Aunque no se afirma expresamente, del fallo que aquí se comenta parece traslucirse, a mi juicio con acierto, que los profesores pueden razonablemente tener una expectativa de privacidad en sus relaciones con los alumnos en el aula.

No obstante, llama la atención que, así como en otros pleitos relacionados con el ámbito laboral la existencia o no de información previa a los afectados sobre la existencia y las características de los medios de vigilancia ha sido el criterio fundamental para decidir si existía una expectativa razonable de intimidad ${ }^{13}$, en la sentencia Antović el Tribunal no se detiene en esta cuestión.

13 Así, en las recientes sentencias de 12 de enero de 2016 (Sala Cuarta), Barbulescu I, párrs. 78 y 132, y de 9 de enero de 2018, López Ribalda y otros, párr. 67. 
Se hace referencia a ello por el Gobierno montenegrino, que alegaba que «las personas afectadas por el sistema de vigilancia, incluidos los demandantes, habían sido debidamente informados», así como por el voto particular disidente, para sostener que participando los profesores "plenamente en una actividad profesional en un entorno casi público», como a su juicio son los anfiteatros de la universidad, y habiendo sido notificados de la videovigilancia en los mismos, «su expectativa razonable de privacidad en ese contexto particular, si la hubiera, era muy limitada». Pero el Tribunal de Estrasburgo, como decía, no lo tiene en cuenta a la hora de decidir la existencia de una expectativa de intimidad por parte de los profesores.

A mi modo de ver, esta cuestión debe tratarse con cuidado porque puede llevar a consecuencias poco deseables. Si la advertencia del uso de cámaras en aulas universitarias elimina $-\mathrm{o}$ reduce considerablemente- la expectativa razonable de intimidad de los afectados, habría que concluir que, hecha tal advertencia, no se cumpliría el requisito de aplicabilidad del art. $8 \mathrm{CEDH}$, en la medida en que se debería entender que la vida privada o familiar del demandante no se ha visto afectada. Pero entonces se cerraría la puerta a la valoración de la licitud o ilicitud de la videovigilancia, lo cual no tiene demasiado sentido $^{14}$. Por eso pienso que es trascendente la afirmación del Tribunal de Estrasburgo de que la existencia de una expectativa razonable de intimidad es un factor «significativo, pero no necesariamente determinante» en la determinación del ámbito de la vida privada. De modo y manera que, aun cuando la notificación previa del uso de la videovigilancia en las aulas de la universidad implicara — cosa que no veo clara — una reducción de la expectativa razonable de intimidad de los profesores, como defendía el voto particular disidente a la sentencia que se comenta, ello no debería considerarse determinante para negar la existencia de vida privada o intimidad en el aula ${ }^{15}$.

14 En España, el deber de comunicación previa a los trabajadores y a sus representantes legales viene recogido en el art 64 ET, a los efectos de instalar un sistema de control del trabajo. Dicho precepto establece expresamente que la empresa deberá preavisar de la instalación de las cámaras, especificando y justificando su ubicación. Así las cosas, y según lo dicho, la conclusión sería que, en España, si se cumple la normativa, nunca habrá expectativa razonable de intimidad en la instalación de cámaras de videovigilancia para el control del trabajo, pues los trabajadores estarán siempre advertidos. ¿Qué pasa si la instalación de las cámaras no está justificada o no es legal? Como se ha señalado, esta circunstancia no se podrá valorar si cerramos el paso a la aplicabilidad del art. $8 \mathrm{CEDH}$ por entender que no había una expectativa de intimidad.

15 En la misma línea, el GT29 ha defendido que, si bien la provisión de información pertinente por el empleador a los trabajadores puede reducir la legítima expectativa de 
En otro orden de cosas, creo importante destacar que la expectativa de intimidad en el aula existe para los profesores, no solo desde el punto de vista de su condición de trabajadores, sino también desde el de las especiales relaciones que se crean con sus alumnos; así como que también estos son titulares de dicha expectativa, aunque esta cuestión no se plantee en el caso Antović. En ese sentido, me habría parecido lo mejor una combinación del enfoque del voto particular concurrente con el de la sentencia. En relación con esta, por cierto, llama la atención que, pese a basar su razonamiento en que las aulas son los lugares de trabajo de los profesores, el TEDH no aplicó para la resolución del caso normas laborales, sino la Constitución de Montenegro de 2007 y la Ley de Protección de Datos Personales montenegrina ${ }^{16}$.

privacidad de estos en el lugar de trabajo, ello no puede ser suficiente para justificar una infracción del derecho a la protección de datos personales (2002: 9).

16 Ivanišević, B. (2018) afirma que el Tribunal no enjuició los hechos con la perspectiva del derecho a la protección de los datos personales. Sostiene que, aunque analizó si la videovigilancia era o no acorde con la citada ley, el propósito era determinar si se había infringido el derecho a la vida privada y no un derecho específico a la protección de datos personales. Esto fue así, en opinión del citado autor, porque el art. $8 \mathrm{CEDH}$ no recoge la protección de datos personales como derecho autónomo. Efectivamente, el Tribunal no podía basar la resolución del caso en un derecho autónomo a la protección de datos personales, ya que el art. $8 \mathrm{CEDH}$ no reconoce tal autonomía. Ahora bien, aunque ese derecho no se menciona expresamente en el citado precepto, el Tribunal de Estrasburgo ha declarado en varias ocasiones que se encuentra incluido en él, como a continuación se verá. Y de hecho creo que resolvió teniendo en mente los datos de carácter personal como parte del contenido del derecho a la vida privada. El voto particular disidente, por su parte, sí se refirió a la inclusión de la protección de datos de carácter personal en el derecho a la vida privada del art. $8 \mathrm{CEDH}$; y consideró que, aunque la grabación obviamente afectaba a datos de personas identificadas o identificables, los profesores demandantes no habían alegado ni probado que la calidad de la grabación fuera tal para permitir la identificación, ni que los datos hubieran sido o pudieran haber sido usados de modo tal que afectaran a la vida privada de aquellos.

En todo caso, sí creo, coincidiendo con Ivanišević, que si el asunto se hubiera enjuiciado exclusivamente con la perspectiva del derecho a la protección de datos personales, las discrepancias en el seno del Tribunal no se habrían producido, sino que todos los jueces habrían concluido que había existido una interferencia en dicho derecho (y después habrían examinado si la misma era conforme a la ley y proporcionada). Como destaca este autor, la protección de datos personales cubre "toda» la información relativa a personas identificadas o identificables, y no hay duda de que en el caso Antovic la videovigilancia y la grabación (pese al carácter borroso del archivo) implicaban tratamiento de información relativa a personas identificables. En cambio, el derecho 


\section{EL DERECHO A LA PROTECCIÓN DE DATOS PERSONALES COMO CONTENIDO DEL DERECHO A LA VIDA PRIVADA DEL ART. 8 CEDH. LA IMAGEN COMO DATO PROTEGIDO}

Junto con el aspecto relativo a la "privacidad» de los profesores, la sentencia Antović plantea la cuestión de la imagen de aquellos como dato de carácter personal. A este respecto, pese a no mencionarse expresamente - como es lógico por su fecha de aprobación-, los datos personales quedan tutelados mediante la protección del derecho a la vida privada y familiar del art. $8 \mathrm{CEDH}$, según afirma el TEDH —-sentencias de 26 de marzo de 1987, Leander; 4 de mayo de 2000, Rotaru; 5 de septiembre de 2017 (Gran Sala), Bârbulescu II; 9 de enero de 2018, López Ribalda y otros-.

En la Carta de Derechos Fundamentales de la UE, en cambio, la protección de datos sí se recoge como un derecho fundamental autónomo, aunque íntimamente relacionado con la vida privada y familiar. En efecto, el art. 7 del mencionado texto garantiza el respeto de la vida privada y familiar, el domicilio y las comunicaciones, mientras que el art. 8 consagra el derecho a la protección de datos de carácter personal. La regulación comunitaria se completa con dos normas: el Reglamento (UE) 2016/679, de 27 de abril de 2016, relativo a la protección de las personas físicas en lo que respecta al tratamiento de datos personales y a la libre circulación de estos datos y por el que se deroga la Directiva 95/46/CE (RGPD ${ }^{17}$ ), y la Directiva (UE) 2016/680, de 27 de abril

a la vida privada solo se refiere a información concerniente a la vida "privada» de una persona, sin que en el caso en cuestión estuviera claro que se hubiera visto afectada la vida privada de los demandantes, como demuestra la división de los jueces en cuatro contra tres.

17 El Reglamento entró en vigor a los veinte días de su publicación, pero no ha sido aplicable hasta el 25 de mayo de 2018 (art. 99). La elección de un reglamento, de aplicación directa y obligatoria en los Estados miembros, pretende lograr la unificación en materia de tratamiento y libre circulación de datos personales y acabar así con las significativas diferencias hasta ahora existentes por la irregular transposición de la Directiva de 1995. Aunque el Reglamento no necesita ser transpuesto en los distintos Estados miembros, el Gobierno español ha iniciado la tramitación de una nueva LOPD, que se encuentra en fase de proyecto, el cual fue aprobado por el Consejo de Ministros el 21 de noviembre de 2017 (BOCG, Serie A, 13-1, de 24 de noviembre de 2017). La exposición de motivos del proyecto justifica las razones de su tramitación. Por un lado, la necesidad de especificaciones o restricciones de las normas del Reglamento por el derecho interno por razones de coherencia y para que las disposiciones nacionales sean comprensibles para sus destinatarios (lo cual es posible debido a las habilitaciones a los Estados miembros a estos efectos). De ello se deriva la obligación de que la normativa 
de 2016, relativa a la protección de las personas físicas en lo que respecta al tratamiento de datos personales por parte de las autoridades competentes para fines de prevención, investigación, detección o enjuiciamiento de infracciones penales o de ejecución de sanciones penales, y a la libre circulación de dichos datos, y por la que se deroga la Decisión Marco 2008/977/JAI del Consejo DOUEL 04-05-2016 $119 \mathrm{C}^{18}$.

En España, el art. 18.4 CE consagró el derecho a la protección de datos de carácter personal como derecho autónomo respecto del de intimidad personal y familiar recogido en el apdo. primero del mismo precepto. El TC (S. 292/2000, de 30 de noviembre, RTC 2000/292) destacó dos diferencias entre los derechos mencionados: la primera es que el derecho fundamental a la protección de datos amplía la garantía constitucional a aquellos datos que, referidos o no al ámbito íntimo de la persona, identifiquen o permitan la identificación de esta o sirvan para cualquier utilidad que en determinadas circunstancias constituya una amenaza para el individuo; y la segunda consiste en que mientras que el derecho a la intimidad personal y familiar permite excluir ciertos datos de una persona del conocimiento ajeno, el derecho a la protección de datos garantiza a los individuos un poder de disposición sobre estos datos; o dicho de otro modo, en tanto que el derecho a la intimidad personal y familiar confiere a la persona el poder jurídico de imponer a terceros

interna que resulte incompatible con el derecho UE quede definitivamente eliminada «mediante disposiciones internas de carácter obligatorio que tengan el mismo valor jurídico que las disposiciones internas que deban modificarse» (SSTJUE de 23 de febrero de 2006, Comisión vs. España; 13 de julio de 2000, Comisión vs. Francia, y 15 de octubre de 1986, Comisión vs. Italia). Por otro lado, la circunstancia de que los reglamentos, pese a su característica de aplicabilidad directa, en la práctica pueden exigir otras normas internas complementarias para hacer plenamente efectiva su aplicación. Por todo ello, el Gobierno ha considerado que la adaptación al Reglamento General de Protección de Datos requiere, en suma, la elaboración de una nueva ley orgánica que sustituya a la LOPD de 1999. Hay ciertas cuestiones, no obstante, que según el Ejecutivo no pueden esperar hasta la aprobación de esa norma (y que no son objeto de reserva de ley orgánica), por lo que se ha adoptado el Real Decreto Ley 5/2018, de 27 de julio, de medidas urgentes para la adaptación del Derecho español a la normativa de la UE en materia de protección de datos, el cual no afecta a la materia estudiada en este trabajo.

18 El tratamiento de datos personales por parte de las autoridades competentes para fines de prevención, investigación, detección o enjuiciamiento de infracciones penales o de ejecución de sanciones penales, incluida la de protección frente a amenazas a la seguridad pública y su prevención, queda expresamente excluido del ámbito de aplicación del Reglamento (UE) 2016/679 en su art. 2.2. d). 
el deber de abstenerse de toda intromisión en la esfera íntima de la persona y la prohibición de hacer uso de lo así conocido, el derecho a la protección de datos atribuye a su titular un haz de facultades consistente en diversos poderes jurídicos cuyo ejercicio impone a terceros deberes jurídicos para garantizar a la persona un poder de control sobre sus datos personales $\left(\mathrm{FJ} 6^{19}\right)$.

Pues bien, entre los datos personales el TEDH incluye la propia imagen, al permitir por sí sola, al menos potencialmente, la identificación de una persona (entre otras, SSTEDH de 28 de enero de 2003, Peck; 15 de enero de 2009, Reklos y Davourlis, párr. 40, y 9 de enero de 2018, López Ribalda y otros, párr. 56). En esta línea, los dos fallos citados en último lugar sostienen que "[l]a imagen de una persona constituye uno de los principales atributos de su personalidad, ya que revela características únicas y la distingue de sus semejantes. El derecho a la protección de la propia imagen es, por tanto, uno de los componentes esenciales del desarrollo personal y presupone el derecho a controlar el uso de dicha imagen».

En España, tampoco hay duda de que la imagen es un dato de carácter personal cubierto por el art. 18.4 CE, como ha afirmado nuestro TC (SS. 292/2000, de 30 de noviembre, RJC 2000/292, FJ 6; 29/2013, de 11 de febrero, EDJ 2013/28049, FJ 5, y 39/2016, de 3 de marzo, RJC 2016/39, FJ 3). Así se desprendía, según el Alto Tribunal, del art. 3 LOPD 15/1999, que considera dato de carácter personal «cualquier información concerniente a personas físicas identificadas o identificables», así como del art. 5.1. f) del RD $1720 / 2007$, que desarrolla dicha ley, que expresamente considera la información gráfica o fotográfica como un dato de carácter personal (como ya hiciera el art. 1.4 del derogado RD 1332/1994, de desarrollo de la LOPD 5/1992, también derogada). Con base en la LOPD de 1999 y el RD de 1994, entonces vigentes, la Instrucción 1/2006, de 8 de noviembre, de la AEPD, sobre el tratamiento de datos personales con fines de vigilancia a través de sistemas de cámaras o videocámaras, corroboró la condición de la imagen como dato de carácter personal (Navalpotro Ballesteros, 2007: 6).

Hoy hay que atender, sin embargo, a lo dispuesto en el RGPD, que desde el 25 de mayo de 2018 es aplicable en todos los Estados miembros, como se ha dicho, sustituyendo a las normativas nacionales. No obstante, la nueva regulación no implica cambio alguno en el concepto de datos personales. En efecto, el citado reglamento, de forma muy similar a la derogada

19 Como destaca Falguera Baró (2016: 14), pese a la distinción entre el derecho a la intimidad del art. 18.1 CE y el derecho a la libertad informática del art. 18.4 del mismo texto legal, en la práctica no suele ser fácil diferenciarlos en el caso de grabaciones en el ámbito laboral. 
Dir. 95/46/CE (art. 2.a), define los datos personales como «toda información sobre una persona física identificada o identificable», entendiendo por «persona física identificable», a estos efectos, «toda persona cuya identidad pueda determinarse, directa o indirectamente, en particular mediante un identificador, como por ejemplo un nombre, un número de identificación, datos de localización, un identificador en línea o uno o varios elementos propios de la identidad física, fisiológica, genética, psíquica, económica, cultural o social de dicha persona» (art. 4.1) RGPD.

Así las cosas, es claro que la imagen de una persona es un dato de carácter personal a los efectos del RGDP, como expresamente ha afirmado la AEPD en reiteradas ocasiones ${ }^{20}$.

Lo que podría plantear alguna duda es si la imagen captada por una videocámara es un dato biométrico, esto es, un tipo concreto de dato personal que el art. 9 RGPD incluye entre las que califica como «categorías especiales de datos personales», a los efectos de aplicarles un régimen específico. De acuerdo con el art. 4.14 del Reglamento, los datos biométricos son «datos personales obtenidos a partir de un tratamiento técnico específico, relativos a las características físicas, fisiológicas o conductuales de una persona física que permitan o confirmen la identificación única de dicha persona, como imágenes faciales o datos dactiloscópicos» (art. 4.14). Pues bien, con base en esa definición tan genérica $^{21}$, hay quien sostiene que las imágenes faciales captadas por videovigilancia - entendiendo esta como un tratamiento técnico específico- pueden constituir datos biométricos en determinados supuestos; concretamente, cuando el responsable del tratamiento tenga la información suficiente como para permitirle vincular las imágenes faciales captadas con personas identificadas, dichas imágenes serán datos biométricos (García Herrero, 2018). Sin embargo, a mi modo de ver, la videovigilancia no puede considerarse como un «tratamiento técnico específico» a los efectos del RGDP, en la medida en que este concepto debe interpretarse en el sentido de tratamiento biométrico, esto es, basado en la medición de datos o procesos biológicos mediante el uso de técnicas matemáticas y estadísticas ${ }^{22}$. De hecho, así es como lo ha entendido

20 Véanse los diversos informes de la AEPD sobre videovigilancia disponibles en http:// bit.ly/2xI6xXF.

21 Que, como señala García Herrero (2018), se debe a que «el legislador europeo no quería pillarse los dedos dejando fuera de esta definición a cualquier invento maravilloso que se desarrolle en el futuro".

22 El Diccionario en línea de la RAE define la biometría como el «estudio mensurativo o estadístico de los fenómenos o procesos biológicos». Disponible en: http://bit.ly/2DCxiT0. 
reiteradamente la AEPD en los informes jurídicos sobre videovigilancia que ha emitido con aplicación del reglamento europeo ${ }^{23}$.

\section{LA INTROMISIÓN EN LA VIDA PRIVADA Y LOS REQUISITOS PARA JUSTIFICARLA}

Una vez concluido que el art. $8 \mathrm{CEDH}$ es aplicable, el Tribunal debe pasar a la segunda fase del análisis, la de establecer si ha existido infracción del citado precepto. A este respecto, del tenor literal de la norma parecería que la infracción solo puede proceder de una injerencia del Estado, esto es, del incumplimiento, por parte de los poderes públicos, de la obligación negativa de no infringir los derechos del sujeto. Sin embargo, aunque el apartado 2 del art. 8 solo se refiera a injerencias procedentes de los poderes públicos, el TEDH afirma que dicho precepto protege también contra las que provienen de un particular, con base en el primer apartado, que garantiza el «respeto» de la vida privada y familiar. Para asegurar dicho respeto, el precepto puede implicar la imposición de obligaciones positivas a los Estados firmantes ${ }^{24}$; en estos casos, lo que el reclamante alega es que las autoridades nacionales deberían haber tomado alguna medida para la protección de sus derechos previstos en el art. 8.1 y no lo hicieron ${ }^{25}$; y el Tribunal deberá valorar esas eventuales medidas que las autoridades nacionales deberían haber adoptado ${ }^{26}$.

23 Dichos informes jurídicos están disponibles en http://bit.ly/2xI6xXF.

Se destaca que la primera vez en la que el TEDH afirmó que la palabra «respeto» del art. $8 \mathrm{CEDH}$ puede implicar la existencia de obligaciones positivas para los Estados contratantes fue con ocasión del caso Marckx, resuelto por sentencia de 13 de junio de 1979, párr. 45 (Roagna, 2012: 60; Harris et al., 2014: 532). Con posterioridad, cabe encontrar la misma idea en, entre otras, las sentencias de 21 de junio de 1988, Berrehab, párr. 21; 19 de febrero de 1996, Gul, párr. 32; 24 de febrero de 1998, Botta, párr. 33, y 24 de junio de 2004, Von Hannover, párr. 98.

Estas medidas pueden consistir en adoptar normas legales o administrativas para asegurar la plenitud de los derechos del art. $8 \mathrm{CEDH}$ o en prevenir las violaciones de tales derechos por parte de terceros (Harris et al., 2014: 533). En la misma línea, De Vries, K. (2018: 669) indica que, aunque el Tribunal de Estrasburgo no distinga entre obligaciones positivas para proteger a los particulares de las interferencias procedentes de otros particulares (obligación de protección) y obligaciones positivas de actuar para lograr cierto resultado o calidad de vida (obligación de satisfacción), ambos tipos se desprenden de los casos enjuiciados.

26 En términos parecidos, Kilkelly (2001: 8-9). Roagna (2012: 60) y Harris et al. (2014: $534)$, por su parte, señalan que, en este tipo de asuntos, el Tribunal de Estrasburgo 
Según el Tribunal de Estrasburgo, la frontera entre las dos categorías de obligaciones que incumben al Estado en virtud del art. 8 no se presta a una definición precisa siempre, pero los principios aplicables a unos y otros son comparables $^{27}$. En ambos casos, hace falta atender a un justo equilibrio entre los intereses concurrentes del individuo y de la sociedad en su conjunto. Además, en las dos hipótesis el Estado goza de un cierto margen de discrecionalidad —entre otras, SSTEDH de 22 de abril de 1997, X., Y, y Z., párr. 41, y 5 de septiembre de 2017 (Gran Sala), Barbulescu II, párr. 111-.

En la sentencia que nos ocupa, el TEDH no aclara si aborda la cuestión con la perspectiva de la injerencia estatal o de las obligaciones positivas del Estado. Se limita a afirmar que las aulas universitarias son lugares de trabajo de los profesores y que la videovigilancia de un empleado en su puesto de trabajo, tanto si es encubierta como si no, constituye una intromisión en su vida privada y, por tanto, una interferencia a los efectos del art. $8 \mathrm{CEDH}$ (párr. 5528). No obstante, en la medida en que la intromisión procedía de una universidad pública, entiendo que el enfoque correcto es el primero $^{29}$.

Ahora bien, como se ha señalado supra, no toda injerencia en la vida privada o familiar implica una violación del art. $8 \mathrm{CEDH}$, ya que su segundo apartado establece tres circunstancias que, si se dan cumulativamente, justifican aquella: que sea acorde a la ley, que persiga uno o más de los fines legítimos que la propia norma recoge y que sea necesaria, en una sociedad democrática, para lograr dichos fines (párr. 55).

Procede realizar dos observaciones al respecto. La primera es que, dado que se trata de restricciones a los derechos garantizados por el Convenio, conforman una lista cerrada y su interpretación debe ser estricta (STEDH de 10 de julio de 1998, Sidiropoulos). Y la segunda es que las condiciones del art. 8.2 $\mathrm{CEDH}$ deben valorarse por el Tribunal de una en una y por el orden en que el

suele limitarse a declarar que el Estado no ha llevado a cabo un balance justo entre los intereses afectados, lo que ha conducido a una violación del $\mathrm{CEDH}$; siendo raros los casos en que va más allá e indica qué medidas concretas podía haber adoptado el Estado para proteger al demandante.

27 Seguramente por ello, como señalan Harris et al. (2014: 505), en alguna ocasión el Tribunal ha resuelto el litigio sin determinar en qué lado de la línea cae. Eso es precisamente lo que ocurrió en la sentencia aquí comentada, como después se verá.

28 Esta afirmación se reitera en la STEDH de 9 de enero de 2018, López Ribalda y otros, párr. 59.

29 En la reciente STEDH de 22 de febrero de 2018, Libert c. Francia, sobre acceso de una empresa pública (ferrocarriles franceses) al contenido de los archivos almacenados en el ordenador del trabajo por un trabajador, sí se adoptó expresamente el enfoque de la injerencia estatal, concluyendo el fallo que no había violación del art. 8 CEDH. 
precepto las nombra. Es decir, en primer lugar se debe comprobar si la medida es conforme a la ley. De no serlo, el análisis no sigue adelante. En cambio, si lo es, el Tribunal enjuiciará si se persigue uno o varios de los fines legítimos recogidos por la norma. En caso negativo, no se valorará la tercera condición. Pero en caso positivo, todavía será preciso decidir si la medida acorde a la ley y destinada a lograr un fin legítimo es necesaria en una sociedad democrática, porque solamente si lo es la interferencia con el derecho al respeto a la vida privada quedará justificada.

En el caso enjuiciado, el Tribunal sostiene que no se había cumplido el primero de los requisitos del art. 8.2 $\mathrm{CEDH}$, por los motivos que a continuación se expondrán. Así las cosas, y siguiendo su proceder habitual, no procede a analizar la concurrencia de las restantes condiciones. No obstante, creo interesante detenernos en todas.

\section{LA CONFORMIDAD CON LA LEY. LA BASE JURÍDICA LEGITIMADORA DE LA VIDEOVIGILANCIA EN LAS AULAS UNIVERSITARIAS}

El TEDH ha declarado que la expresión «de acuerdo con la ley» del art. 8.2 $\mathrm{CEDH}$ requiere, en primer lugar, que las medidas utilizadas tengan alguna base en la normativa nacional, y, en segundo lugar, que dicha normativa proporcione mecanismos de salvaguarda frente a las arbitrariedades. Ello implica que la ley debe ser suficientemente clara en sus términos para proporcionar a los ciudadanos una indicación adecuada sobre las circunstancias y condiciones en las que las autoridades están legitimadas para recurrir a tales medidas, a fin de que aquellos puedan prever las consecuencias ${ }^{30}$.

En resumidas cuentas, para que una injerencia sea acorde con la ley, son necesarios dos requisitos: uno de carácter formal (que la medida esté recogida en una ley nacional) y otro sustantivo (que dicha ley sea accesible y previsible) (Schabas, 2015: 402-40331).

30 Entre otras, SSTEDH de 24 de marzo de 1988, Olsson, párr. 61; 24 de abril de 1990, Kruslin, párrs. 27 y 30; 25 de junio de 1997, Halford, párr. 49; 16 de febrero de 2000, Amann, párrs. 55 y 56; 25 de septiembre de 2001, P. G. y J. H., párrs. 44 y 61, y 3 de abril de 2007, Copland, párr. 45. Ahora bien, en la sentencia Olsson se reconoce que una precisión absoluta es inalcanzable y que la necesidad de evitar rigideces excesivas y de adaptar la ley a las circunstancias cambiantes implica que muchas leyes están redactadas en términos vagos, en mayor o menor medida.

31 A estos efectos, el TEDH interpreta «ley nacional» en sentido amplio, ya que incluye en ella no solamente normas positivas del Estado afectado, sino también reglas profesionales, principios no escritos de common law, normas de la UE y tratados internacionales. Sin embargo, es más dudoso el supuesto de normas administrativas o 
En el caso Antović, el Tribunal declara como normativa nacional aplicable la formada por los preceptos constitucionales que garantizan el derecho a la vida privada y familiar, incluidos los datos de carácter personal (arts. 40 y 43 Constitución de Montenegro de 2007) y por los arts. 10, 21, 35 y 36 de la Ley de Protección de Datos Personales (LPDP).

De acuerdo con estas normas, los datos personales solo pueden ser procesados previo consentimiento de la persona afectada, la cual puede revocarlo en cualquier momento (art. 10 LPDP). Además, la persona responsable del tratamiento de los datos recogidos debe informar a la persona afectada de, entre otras cosas, los fundamentos legales, el propósito del tratamiento y el derecho de acceso a la información (art. 21 LPDP). El art. 35.1 señala, por su parte, que las instituciones públicas pueden instalar videovigilancia en las áreas de acceso a instalaciones oficiales, a lo que el art. 36 añade que la videovigilancia en lugares oficiales o empresas puede utilizarse para asegurar la seguridad de las personas o los bienes o para la protección de datos confidenciales siempre que estos fines no puedan conseguirse por ningún otro medio.

Sobre esa base, el TEDH, en la misma línea que la agencia, entendió que no se había respetado el art. 35.1 LPDP, ya que las cámaras no se habían instalado en las áreas de acceso a la facultad, sino en el interior de los anfiteatros. Asimismo, en cuanto al art. 36, declaró que la vigilancia de la enseñanza, que había sido uno de los motivos alegados por el decano para la instalación de la videovigilancia, no está recogida por la ley como uno de los fines que justificaban aquella; así como que, respecto a la protección de las personas y los bienes, que sí se recoge entre tales fines, la agencia estatal de protección de datos admitió expresamente que no existía evidencia de riesgo para los mismos, sin que el Gobierno hubiera aportado prueba suficiente en contrario ni hubiera justificado la valoración de algún otro medio alternativo.

Por estas razones, el TEDH concluye afirmando la violación del art. 8 $\mathrm{CEDH}$, por faltar los requisitos legales que justificarían la intromisión en la vida privada de los demandantes ${ }^{32}$.

Si los hechos hubieran ocurrido en España, por la fecha en que se dieron se habría aplicado el art. 6 LOPD, según el cual el tratamiento de los datos

reglamentarias o cualesquiera otras caracterizadas por un alto grado de flexibilidad o discrecionalidad (Kilkelly: 2001, 25; Roagna, 2012: 37).

32 En el mismo sentido, los magistrados firmantes del voto particular concurrente sostuvieron que el art. $8 \mathrm{CEDH}$ no impide el uso de videovigilancia en los auditorios de la universidad, siempre que cumpla los requisitos que la propia norma establece, entre los que señalan que haya una base legal —que a su juicio no existió en el caso enjuiciado-, que el fin de la vigilancia sea limitado y que existan garantías frente al abuso. 
de carácter personal exige el consentimiento inequívoco del afectado o una habilitación legal expresa. Esta habilitación legal se da, entre otros supuestos, cuando los datos de carácter personal se recojan para el ejercicio de las funciones propias de las Administraciones públicas en el ámbito de sus competencias y cuando se refieran a las partes de un contrato o precontrato de una relación negocial, laboral o administrativa y sean necesarios para su mantenimiento o cumplimiento.

Pues bien, el ejercicio de las funciones propias de las Administraciones públicas en el ámbito de sus competencias habría legitimado el uso de cámaras de videovigilancia con fines de seguridad, mientras que la captación y grabación de imágenes de los profesores de universidad con un fin de control de la enseñanza, entendiendo este como control laboral, quedaría justificado en el hecho de tratarse de datos referidos a las partes de un contrato de una relación negocial, laboral o administrativa y necesarios para su mantenimiento o cumplimiento, según la interpretación amplia que de este supuesto hace el TC español. En este sentido, el citado órgano ha declarado que «en el ámbito laboral el consentimiento del trabajador pasa, por tanto, como regla general, a un segundo plano pues el consentimiento se entiende implícito en la relación negocial siempre que el tratamiento de datos de carácter personal sea necesario para el mantenimiento y el cumplimiento del contrato firmado por las partes, lo que abarca, sin duda, las obligaciones derivadas del contrato de trabajo» (STC 39/2016, de 3 de marzo, FJ 3).

En la misma línea, la AEPD afirma que el artículo 20.3 del Texto Refundido del Estatuto de los Trabajadores, aprobado por Real Decreto Legislativo 2/2015, de 23 de octubre (ET), en relación con el art. 6 LOPD, legitimaría, en principio, al empleador para tratar las imágenes de los trabajadores en el ámbito laboral con carácter general (Informe 0475/201433). De acuerdo con el citado art. 20.3 ET, el empresario «podrá adoptar las medidas que estime más oportunas de vigilancia y control para verificar el cumplimiento por el trabajador de sus obligaciones y deberes laborales, guardando en su adopción y aplicación la consideración debida a su dignidad y teniendo en cuenta, en su caso, la capacidad real de los trabajadores con discapacidad».

No hay previsión específica, en cambio, en cuanto a los empleados públicos, y conviene recordar que los profesores de universidades públicas pueden estar unidos con ella por virtud de una relación laboral o administrativa. No obstante, la STS de 2 de julio de 2007 (Rec. 5017/2003) declaró que la

33 Preciado Doménech (2017), sin embargo, sostiene que el art. 20.3 ET no cumple con los estándares europeos de previsibilidad mínimos de la ley habilitante exigidos por la jurisprudencia del Tribunal de Estrasburgo. 
obligación de aquellos de cumplir con su horario de trabajo es inherente a la relación que les une con la Administración, por lo que el control, por parte de esta, de dicho cumplimiento, utilizando un mecanismo de lectura biométrica de la mano mediante un escáner que utiliza rayos infrarrojos, no necesita el consentimiento previo de los afectados, con base en el art. 6.2 LOPD. Cabría entender, por tanto, con base en esta sentencia, que la citada norma era fundamento suficiente del control laboral de los empleados públicos con carácter general.

Por otra parte, en el ámbito universitario hay que hacer referencia también a la LO 4/2007, de 12 de abril, por la que se modifica la LO 6/2001, de 21 de diciembre, de Universidades. Dicha norma declara aplicable la regulación de la LOPD al tratamiento y la cesión de datos derivados de lo dispuesto, y ordena a las universidades la adopción de las medidas de índole técnica y organizativa necesarias para garantizar la seguridad de los datos de carácter personal y evitar su alteración, tratamiento o acceso no autorizados.

El nuevo RGPD de 2016 mantiene el fundamento de la licitud del tratamiento en el consentimiento del interesado o en la concurrencia de alguna de las circunstancias que enumera el art. 6.1 en las letras b) a h). Estas circunstancias son más numerosas que las previstas en la LOPD, habiéndose añadido los supuestos en que el tratamiento sea necesario para el cumplimiento de una obligación legal aplicable al responsable del tratamiento, para proteger intereses vitales, no solo del interesado sino también de otra persona física, o para satisfacer intereses legítimos perseguidos por el responsable del tratamiento o por un tercero (sin exigir que los datos figuren en fuentes accesibles al público), siempre que sobre dichos intereses no prevalezcan los intereses o los derechos y libertades fundamentales del interesado que requieran la protección de datos personales, en particular cuando el interesado sea un niño.

En el caso de videovigilancia en las aulas de una universidad pública, la base jurídica legitimadora de entre las previstas en el RGPD vendría dada por la necesidad del tratamiento para el cumplimiento de una misión realizada en interés público o en el ejercicio de poderes públicos conferidos al responsable del tratamiento y por la satisfacción de intereses legítimos perseguidos por el responsable del tratamiento o por un tercero ${ }^{34}$.

34 En opinión de Blázquez Aguado (2017: 7), en cambio, ninguna de las excepciones a la exigencia de consentimiento expreso impuesta por el art. 6 RGPD es aplicable al contexto laboral como hasta ahora. Concretamente afirma que es complicado justificar la falta de consentimiento del trabajador por el hecho de que el tratamiento sea necesario para la ejecución de un contrato en el que es parte el interesado. A mi modo de ver, sin embargo, esta circunstancia sería equivalente a la prevista en el art. 6 
A lo dispuesto en el art. 6 RGDP, añade el art. 88, específicamente dedicado al tratamiento en el ámbito laboral, que los Estados miembros podrán, a través de disposiciones legislativas o de convenios colectivos, establecer normas más específicas para garantizar la protección de los derechos y libertades en relación con el tratamiento de datos personales de los trabajadores en el ámbito laboral. Dichas normas incluirán medidas adecuadas y específicas para preservar la dignidad humana de los interesados, así como sus intereses legítimos y sus derechos fundamentales, prestando especial atención a la transparencia del tratamiento, a la transferencia de los datos personales dentro de un grupo empresarial o de una unión de empresas dedicadas a una actividad económica conjunta y a los sistemas de supervisión en el lugar de trabajo.

Sobre esa base, el art. 22 del Proyecto de Ley Orgánica de Protección de Datos de Carácter Personal, regulador de los tratamientos de datos personales con fines de videovigilancia ${ }^{35}$, dispone que las personas físicas o jurídicas, públicas o privadas, podrán llevar a cabo el tratamiento de imágenes a través de sistemas de cámaras o videocámaras con dos finalidades: a) preservar la seguridad de las personas y bienes, así como de sus instalaciones, y b) el ejercicio de las funciones de control de los trabajadores previstas en el artículo 20.3 ET, siempre que estas funciones se ejerzan dentro de su marco legal y con los límites inherentes al mismo ${ }^{36}$.

Ahora bien, la existencia de una habilitación legal que ampare la instalación de cámaras no es suficiente, sino que es precisa la información al afectado por el tratamiento de datos. En este sentido, antes de la entrada en vigor del RGPD, debía atenderse al art. 5.4 LOPD, que impone que la persona afectada haya sido informada por el responsable del fichero o su representante «de forma expresa, precisa e inequívoca», ya sea con anterioridad, ya sea en

LOPD en relación con los datos referidos a las partes de un contrato de una relación negocial, laboral o administrativa y necesarios para su mantenimiento o cumplimiento. Por consiguiente, todo dependerá de si el TC mantiene respecto del art. 6 RGPD la interpretación amplia que ha venido haciendo en relación con el art. 6 LOPD.

Debe acogerse con agrado la regulación legal concreta de esta materia en el Proyecto, porque, como señalan Miró Morros (2014: 1) y Falguera Baró (2016: 20), uno de los factores que más contribuyen a que el uso de los dispositivos de videovigilancia en el ámbito laboral sea controvertido es la ausencia de una regulación específica, que obliga, en opinión del segundo autor citado, a jueces y tribunales a hacer funciones de protolegislador.

36 A estos efectos hay que tener en cuenta, no obstante, que, según el Comité de Ministros de la UE, los Estados miembros no deberían permitir el uso de sistemas como la videovigilancia para el propósito directo y principal de control de la actividad y el comportamiento de los empleados — Recommendation CM/Rec (2015) 5: 15.1—. 
los tres meses siguientes al momento del registro de los datos, del contenido del tratamiento, de la procedencia de los datos, de la existencia de un fichero o tratamiento de datos de carácter personal, de la finalidad de la recogida de estos y de los destinatarios de la información, de la posibilidad de ejercitar los derechos de acceso, rectificación, cancelación y oposición, y de la identidad y dirección del responsable del tratamiento o, en su caso, de su representante ${ }^{37}$.

El derecho a ser informado de quién posee los datos personales y con qué fin es, según el TC, «elemento caracterizador de la definición constitucional del art. 18.4 CE, de su núcleo esencial», y solo si existe una habilitación legal expresa puede limitarse; cosa que no ocurre en el ámbito de las relaciones laborales (SSTC 29/2013, de 11 de febrero, EDJ 2013/28049, FJ 7, y 39/2016, de 3 de marzo, RJC 2016/39, FJ 3). A estos efectos, mientras que en la STC 29/2013 se afirmó que esa información debe darse de forma específica, sin que sea suficiente el hecho de que existan carteles anunciando la instalación de cámaras y captación de imágenes en el recinto universitario, como exige la ya citada Instrucción 1/2006 de la AEPD ${ }^{38}$, en la reciente STC 39/2016 (del Pleno) se corrige la anterior doctrina y se declara que a efectos de cumplir con la obligación de información previa basta con el cumplimiento de los requisitos específicos de información a través del distintivo, de acuerdo con la Instrucción

$37 \mathrm{El}$ art. 5.5 LODP establece algunas excepciones al deber de información, que no son relevantes en el caso que nos ocupa.

38 Con este fundamento el TC declaró nulas las sanciones que la Universidad de Sevilla había impuesto a uno de sus trabajadores, con base en las grabaciones realizadas por unas cámaras de videovigilancia instaladas en el recinto universitario (vestíbulos y zonas de paso públicos) como única prueba; y ello porque no se había informado al trabajador sancionado sobre la utilización de dichas cámaras para la supervisión de su jornada laboral (de cuyo incumplimiento se tenían fundadas sospechas), siendo así que la autorización de la AEPD para la instalación del sistema de videograbación no se concedió con esa finalidad. Según el Tribunal, «[n]o contrarresta esa conclusión que existieran distintivos anunciando la instalación de cámaras y captación de imágenes en el recinto universitario, ni que se hubiera notificado la creación del fichero a la Agencia Española de Protección de Datos; era necesaria además la información previa y expresa, precisa, clara e inequívoca a los trabajadores de la finalidad de control de la actividad laboral a la que esa captación podía ir dirigida. Una información que debía concretar las características y el alcance del tratamiento de datos que iba a realizarse, esto es, en qué casos las grabaciones podían ser examinadas, durante cuánto tiempo y con qué propósitos, explicitando muy particularmente que podían utilizarse para la imposición de sanciones disciplinarias por incumplimiento del contrato de trabajo». En contra de esta doctrina, Casino Rubio (2013) y Talens Visconti (2013: 3). 
1/2006; «sin que haya que especificar, más allá de la mera vigilancia, la finalidad exacta que se le ha asignado a ese control» $\left(\mathrm{FJ}^{49}{ }^{39}\right.$.

El TS ha aplicado la doctrina de la STC de 3 de marzo de 2016 en sus últimos pronunciamientos en esta materia, a saber, las SSTS 630/2016, de 7 de julio (RJ 2016/77), de 31 de enero (RJ 2017/1427); 86/2017, de 1 de febrero (RJ 2017/1105); 96/2017, de 2 de febrero (RJ 2017/162840).

En opinión de Bru y Gutiérrez (2017: 2), la nueva línea interpretativa de los tribunales españoles no cumple los requisitos de transparencia y refuerzo de información establecidos por el RGPD y por el GT29 en su Opinión 2/2017 sobre el tratamiento de datos en el trabajo.

Veamos. El Reglamento europeo añade un nuevo principio, el de transparencia (art. 5.1 a), que, además de imponer el deber de informar de ciertas cuestiones a la persona afectada, exige que la información y comunicación relativa al tratamiento de los datos se presente al interesado de forma concisa, transparente, inteligible y de fácil acceso, y con un lenguaje claro y sencillo. La información puede facilitarse por escrito o por otros medios (art. 12.1), lo que teóricamente permitiría el formato del cartel con los requisitos exigidos por la

39 En este caso, la recurrente en amparo fue una trabajadora de Bershka España que fue despedida por haberse apropiado de dinero de la caja de la tienda donde prestaba sus servicios. La prueba de ello se obtuvo mediante una cámara de videovigilancia que la empresa instaló — previa comprobación de múltiples irregularidades que hacían sospechar lo que después se demostró-, enfocando directamente a la caja que manejaba la trabajadora despedida, y de la que advirtió mediante la colocación, en un lugar visible del escaparate, del distintivo informativo exigido por la Instrucción 1/2006 de la AEPD. Pues bien, para el TC, «teniendo la trabajadora información previa de las cámaras de videovigilancia a través del correspondiente distintivo informativo, y habiendo sido tratadas las imágenes captadas para el control de la relación laboral, no puede entenderse vulnerado el art. 18.4 CE» (FJ 4). En contra de la tesis mayoritaria se manifestaron los votos particulares del magistrado Valdés Dal-Re, al que se adhirió la magistrada Asúa Batarrita, y del magistrado Xiol Ríos, por entender que el derecho de los trabajadores a ser informados sobre el destino de sus datos personales obtenidos por el empleador forma parte del núcleo del habeas data y, por tanto, no puede verse cumplido con un mero anuncio con el correspondiente distintivo visible en un cristal. La importancia de esta sentencia del Pleno del TC al haber corregido de forma significativa la doctrina que hasta entonces había mantenido el Tribunal ha provocado numerosos análisis doctrinales. Véanse, por todos, González González (2016), Mayor Gómez (2016), Rodríguez Escanciano (2016).

40 Si bien la sentencia 77/2017 contó con el voto particular de la magistrada Segoviano Astaburuaga, al que se adhirieron el magistrado Agustí Juliá y la magistrada Viroles Piñol. 
ley. Ahora bien, los arts. 13 y 14 RGPD especifican la información concreta que debe facilitarse al interesado, distinguiendo en función de que los datos personales se obtengan de él o no. En este segundo caso, que es el que aquí interesa, el art. $14.1 \mathrm{c}$ ) se refiere «a los fines del tratamiento a que se destinan los datos personales, así como la base jurídica del tratamiento ${ }^{41}$ », lo que, a mi juicio, choca con la afirmación de los tribunales españoles de que basta con advertir de la existencia de la vigilancia, sin necesidad de especificar la finalidad exacta que se le ha asignado a ese control ${ }^{42}$.

El art. 22 del Proyecto de LOPD, que, como se ha dicho, regula específicamente los tratamientos de datos personales con fines de videovigilancia, se refiere también a las exigencias de información. En el caso de que la finalidad sea preservar la seguridad de las personas y los bienes, así como de sus instalaciones, dispone que el deber de información previsto en el art. 12 RGPD se entenderá cumplido mediante la colocación de un dispositivo informativo en lugar suficientemente visible, identificando, al menos, la existencia del tratamiento, la identidad del responsable y la posibilidad de ejercitar los derechos

41 El GT29 ha afirmado en diversas ocasiones que los empleados deberían recibir información completa, clara y efectiva sobre el control laboral llevado a cabo por el empleador. Dicha información debería comprender el alcance de la medida, los motivos para adoptarla, los detalles de la misma (¿quién?, ¿qué?, ¿`cómo?, ¿cuándo?) y los medios de queja y protección contra la medida (2002: 14-15; 2017: 3, 6, 23-15). En la misma línea, la Recomendación del Comité de Ministros de la UE a los Estados miembros en materia de tratamiento de datos en el entorno laboral señala que el uso de sistemas de captación de información como la videovigilancia debería estar sujeto a determinadas salvaguardas recogidas en el principio 21 , en especial a la consulta a los representantes de los empleados (2015: 15.2).

42 No obstante, el art. 14.5 RGPD exime de la obligación de facilitar la información prevista en los apartados anteriores y en la forma exigida en ciertos casos, como cuando la comunicación de dicha información resulte imposible o suponga un esfuerzo desproporcionado, si bien en tales casos el responsable adoptará medidas adecuadas para proteger los derechos, libertades e intereses legítimos del interesado, inclusive haciendo pública la información [letra b)]. Esta norma no ampararía la falta de notificación individual a los profesores de la instalación de cámaras de grabación en las aulas o en otros lugares de la universidad, pero quizá sí a los alumnos.

Por otro lado, el art. 25 RGPD autoriza a la Unión y a los Estados miembros para adoptar medidas legislativas que limiten el alcance de las obligaciones y los derechos establecidos en los arts. 12 a 22, cuando tal limitación respete en lo esencial los derechos y las libertades fundamentales y sea una medida necesaria y proporcionada en una sociedad democrática para salvaguardar ciertos intereses que el precepto enumera, ninguno de los cuales entra en juego en el supuesto del uso de videovigilancia para control empresarial. 
previstos en los artículos 15 a 22 del citado reglamento. Se establece además que, en todo caso, el responsable del tratamiento deberá mantener a disposición de los afectados la información a la que se refiere el citado reglamento (art. 22.4 Proyecto).

Cuando la videovigilancia se utilice para el ejercicio de las funciones de control de los trabajadores previstas en el artículo $20.3 \mathrm{ET}$, los empleadores deberán informar a los trabajadores acerca de la medida. Además, para zanjar la polémica hasta ahora existente, se añade que en el supuesto de que las imágenes hayan captado la comisión flagrante de un acto delictivo, la ausencia de la información a la que se refiere el apartado anterior no privará de valor probatorio a las imágenes, sin perjuicio de las responsabilidades que pudieran derivarse de dicha ausencia (art. 22.5 Proyecto).

\section{LOS FINES LEGÍTIMOS}

El apdo. 2 del art. 8 CED recoge una lista cerrada de fines que legitiman la interferencia. Son los siguientes: la seguridad nacional, la seguridad pública, el bienestar económico del país, la defensa del orden y la prevención del delito, la protección de la salud o de la moral, o la protección de los derechos y las libertades de los demás.

La doctrina critica tanto la indefinición como el elevado número de fines (Rebollo Delgado, s. f.: 283), que favorece a los Estados demandados, los cuales no suelen tener problema para justificar la interferencia con base en alguno de ellos (Harris et al., 2014: 510); especialmente porque el TEDH tiende a aplicarlos de forma amplia y liberal (Schabas, 2015: 404).

En el supuesto que nos ocupa, los fines que podrían haber justificado la injerencia habrían sido la defensa del orden y la prevención del delito ${ }^{43}$, por lo que se refiere a la evitación de robos y disturbios en la universidad, y la protección de los derechos y las libertades de los demás ${ }^{44}$, respecto a los derechos de la Universidad de Montenegro en cuanto que empleador. Sin embargo, según se ha visto, pese a que la sentencia parte de la consideración de las aulas universitarias como lugares de trabajo de los profesores demandantes y se refiere a la inclusión de las relaciones laborales en el ámbito de la vida privada, la solución del caso no se basa en la aplicación de normas laborales ni

43 Quizá unidas a la seguridad pública, que, como destaca Roagna (2012: 42), es un fin que raramente se invoca de forma aislada, sino en unión con otros, como la seguridad nacional o el de la defensa del orden y la prevención del delito.

44 Tal y como señala Roagna (2012: 44), este fin está formulado en términos muy amplios y sirve para cubrir una gran variedad de situaciones. 
se busca con la perspectiva de la obligación positiva del Estado de garantizar el equilibrio entre el derecho del empleado al respeto de su vida privada y su correspondencia y el interés del empresario en la protección de sus derechos de dirección y organización ${ }^{45}$.

Así, da la impresión de que el enfoque declarado por el Tribunal no coincide con el realmente adoptado, el cual, curiosamente, se corresponde con el que los magistrados firmantes del voto particular concurrente dicen que habrían preferido que adoptara aquel y que, a mi modo de ver, era el más acertado. En efecto, tanto la sentencia como el voto particular concurrente ponen de manifiesto que en las aulas u otros espacios de impartición de docencia se entablan relaciones que van más allá de esta, pues afectan también a las interacciones de otro tipo relacional y social entre el profesorado y el alumnado (y entre los alumnos, no lo olvidemos), por lo que los hechos representaban algo más que una interferencia del empleador en la vida privada de sus empleados ${ }^{46}$.

Por lo que se refiere a España, la concreción de esos fines legítimos se recoge en el art. 6 LOPD, el art. 6 RGDP y el art. 22 Proyecto LOPD, como se ha visto en el apartado anterior, al que me remito.

\section{LA NECESIDAD DE LA INTERFERENCIA EN UNA SOCIEDAD DEMOCRÁTICA. EL PRINCIPIO DE PROPORCIONALIDAD}

Comprobada la previsión de la medida que implica una injerencia en el derecho a la vida privada, así como la existencia de un fin legítimo para la misma, el último requisito necesario para justificar la intromisión es que sea necesaria en una sociedad democrática. A este respecto el TEDH ha declarado que si bien «necesario» no es sinónimo de «indispensable», tampoco puede identificarse con «admisible», «ordinario», «útil», «razonable» o «deseable» (S. de 7 de diciembre de 1976, Handyside, párr. 48); así como que el concepto de necesidad implica que una interferencia responde a una «apremiante necesidad social» $y$, en particular, que es proporcionada al fin legítimo que persigue (S. de 24 de marzo de 1988, Olsson, párr. 67).

Se dice que, en última instancia, la determinación de lo que es necesario en una sociedad democrática debe hacerse por referencia al equilibrio entre los derechos de los individuos y el interés público, a través de la aplicación del

45 A diferencia de las SSTEDH de 12 de junio de 2016, Barbulescu I, párr. 54, y de 9 de enero de 2018, López Ribalda y otros, párr. 61.

46 En términos parecidos, Rojo Torrecilla (2017). 
principio de proporcionalidad (Kilkelly, 2001: 31; Roagna, 2012: 44; Harris et al., 2014: 519).

Pues bien, a la hora de llevar a cabo este juicio, el TEDH concede un amplio margen de discrecionalidad a los Estados contratantes ${ }^{47}$. Y ello porque considera que normalmente están en mejor posición para comprobar la necesidad y la proporcionalidad de una medida en el contexto cultural y socioeconómico correspondiente ${ }^{48}$. No obstante, aunque las autoridades nacionales realizan la comprobación inicial de necesidad, la evaluación final sobre si las razones aducidas para la injerencia son relevantes y suficientes y, por tanto, conformes con el CEDH, debe llevarse a cabo por el Tribunal de Estrasburgo (SSTEDH de 7 de diciembre de 1976, Handyside, párr. 49, y 2 de junio de 2009, Szuluk, párr. 45).

Para la valoración de la proporcionalidad, el Tribunal toma en consideración factores diversos. Así, se considerará desproporcionada una medida cuando no era necesaria o cuando el objetivo perseguido no podía lograrse con la misma; o cuando existían otras medidas menos severas que pudieran haberse aplicado logrando el mismo objetivo (Harris et al., 2014: 519; Schabas, 2015: 406). Por el contrario, se puede considerar que la medida no será desproporcionada si es limitada en su aplicación y efectos, y viene acompañada de medidas legales de salvaguarda que impidan que el individuo esté sujeto a un trato arbitrario (STEDH de 27 de agosto de 1997, M. S.).

También el TC español exige, para admitir la constitucionalidad de las medidas empresariales restrictivas de derechos fundamentales, la superación del test de proporcionalidad, formado por tres elementos: idoneidad, necesidad y proporcionalidad en sentido estricto, según los cuales la medida ha de ser adecuada y necesaria para alcanzar el fin que se propone, de modo que no exista otra medida menos lesiva para el derecho fundamental afectado que hubiera bastado para conseguir aquel fin, y además ha de ser equilibrada, en el sentido de derivarse de ella más beneficios para el interés general que perjuicios sobre otros bienes o valores en conflicto (STC 98/2000, de 10 de abril, EDJ 2000/4330; STC 29/2013, de 11 de febrero, EDJ 2013/28049, FJ 5, y

47 Así lo señaló la STEDH de 7 de diciembre de 1976, Handyside, párr. 48, que aclaró que dicho margen de apreciación se concede tanto al legislador como a las instituciones (las judiciales, entre otras) llamadas a interpretar y aplicar las leyes en vigor.

En los casos en que no hay consenso entre los Estados miembros del Consejo de Europa en cuanto a la relevancia del interés en juego o el mejor modo de protegerlo, especialmente cuando el caso está relacionado con aspectos éticos o morales, el margen de apreciación del Estado en cuestión será mayor; mientras que si la existencia de un principio o regla se considera "común» o «europeo», el margen será menor (Roagna, 2012: 45; Harris et al., 2014: 513). 
STC 39/2016, de 3 de marzo, RJC 2016/39, FJ 5). Se trata, en definitiva, de respetar el principio de intervención mínima (Goñi Sein, 2007: 41; Blázquez Aguado, 2017: 3), de modo que la limitación de los derechos fundamentales sea la estrictamente indispensable (Mercader Uguina, 2002: 103; Blázquez Aguado, 2017: 3).

El RGPD recoge el principio de proporcionalidad en el art. 5.1 c), con la denominación «minimización de datos», al establecer que los datos personales serán «adecuados, pertinentes y limitados a lo necesario en relación con los fines para los que son tratados». El considerando 39 explica que ello se traduce, en lo que aquí interesa, en que «los datos personales solo deben tratarse si la finalidad del tratamiento no pudiera lograrse razonablemente por otros medios».

Por lo que se refiere a la videovigilancia, el GT29 ha señalado que el principio de proporcionalidad debe aplicarse tanto respecto a la adopción de la medida como a la forma de llevarla a cabo. En cuanto al primer aspecto, en línea con lo establecido en el cdo. 39 RGPD, afirma que la videovigilancia solo debe usarse de forma subsidiaria, es decir, cuando realmente exista una justificación. Respecto al segundo, indica que la proporcionalidad exige tener en cuenta, por un lado, consideraciones como el ángulo visual, el tipo de equipamiento utilizado, la ubicación del mismo, la posibilidad de alejar y acercar la imagen, la existencia de función de congelado de imágenes, la conexión con un "centro" para enviar alertas de sonido y/o imagen, y las medidas adoptadas como consecuencia de la videovigilancia; y, por otro, la decisión de grabar y guardar las imágenes y el tiempo de almacenamiento (2004: 18-20).

También la Instrucción 1/2006 hace especial referencia a la necesidad de ponderar los bienes jurídicos protegidos en relación, concretamente, con la instalación de sistemas de videocámaras. Así, señala que la instalación de este tipo de dispositivos deberá respetar el principio de proporcionalidad, valorando así la posibilidad de adoptar otros medios menos intrusivos a la intimidad de las personas, con el fin de prevenir interferencias injustificadas en los derechos y libertades fundamentales. En este sentido, la AEDP afirma que «[1]a instalación de cámaras de videovigilancia sería una medida proporcional y justificada si se cumplen los siguientes requisitos: 1 . Que se trate de una medida susceptible de conseguir el objetivo propuesto. 2. Que no exista otra medida más moderada para la consecución de tal propósito con igual eficacia. 3. Que la misma sea ponderada o equilibrada, por derivarse de ella más beneficios o ventajas para el interés general que perjuicios sobre otros bienes o valores en conflicto» (Informe 0186/201749).

49 La reciente SJS n.2 de Sevilla de 26 de febrero de 2016 (AS 2016/580) consideró que la instalación de cámaras de videovigilancia en los baños de una residencia de discapa- 
En la sentencia que nos ocupa el Tribunal no se ocupó del juicio de proporcionalidad, en la medida en que, como ya se ha dicho, el no acomodo de la medida a la ley le llevó a considerar infringido el art. $8 \mathrm{CEDH}$, sin necesidad de valorar el resto de requisitos. No obstante, merece la pena preguntarse si el uso de videovigilancia en las aulas universitarias, de haber gozado de base jurídica y responder a un fin legítimo, habría sido proporcional. A la vista de los factores señalados, mi conclusión es que no, tanto porque la medida no parecía ser eficaz para los objetivos pretendidos como porque, al menos para uno de ellos, se podría haber utilizado otro medio menos invasivo.

Por lo que se refiere a la primera cuestión, cabe recordar que, según declaró el propio Gobierno montenegrino en su defensa, las cámaras proporcionaban una imagen a distancia sin resolución clara y no tenían zoom, por lo que los rasgos de las personas no podían ser fácilmente reconocidos, además de que no grababan sonido. Un sistema de videovigilancia con tales características ¿podía servir para lograr los objetivos alegados por el decano (a saber, control de la enseñanza y seguridad)? Y si no era útil a tales efectos, ¿cómo podría ser necesario ${ }^{50}$ ?

Respecto a la segunda, el fin de seguridad se habría logrado instalando las cámaras en las áreas de acceso a la facultad, que es, además, lo único que permite el art. 35.1 de la Ley de Protección de Datos de Montenegro. Y el control de la enseñanza puede llevarse a cabo mediante otros métodos no lesivos de los derechos de los profesores, como encuestas de docencia al alumnado o sistemas de control de horario, por ejemplo.

\section{Bibliografía}

Agencia Española de Protección de Datos (2014). Informe 0475/2014. Sistema de videovigilancia en guardería para control laboral. Disponible en: https://bit.ly/2MrsWx 9 .

Agencia Española de Protección de Datos (2017). Informe 0186/2017. Sistema de videovigilancia en aulas universitarias para control de exámenes. Disponible en: https:// bit.ly/2x4KvhC.

citados psíquicos no superó el juicio de proporcionalidad. Véase, al respecto, Camos Victoria (2017).

50 Rojo Torrecilla (2017) llama también la atención sobre este punto. Se pregunta «el motivo de las afirmaciones del decano de la Facultad de Matemáticas de pretender controlar la docencia, que es mucho más que la mera presencia, del profesorado» sobre la base de la "poca» calidad de las grabaciones para reconocer a las personas presentes en los lugares vigilados. 
Article 29. Data Protection Working Party (2002). Working document on the surveillance of electronic communications in the workplace (5401/01/EN/Final. WP 55). Adopted on 29 May 2002. Disponible en: https://bit.ly/2x8t3Jb.

Article 29. Data Protection Working Party (2004). Opinion 4/2004 on the Processing of Personal Data by means of Video Surveillance (11750/02/EN. WP 80). Adopted on 11 February 2004. Disponible en: https://bit.ly/2NH8ahM.

Article 29. Data Protection Working Party (2017). Opinion 2/2017 on data processing at work (17/EN WP 249). Adopted on 8 June 2017. Disponible en: https://bit. ly/2QssDpc.

Blázquez Aguado, E. M. (2017). La implantación de un protocolo de videovigilancia en el centro de trabajo. Revista Aranzadi de Derecho y Nuevas Tecnologías, 43, 1-18.

Bru, P. y Gutiérrez, J. (2017). Sobre la videovigilancia en el centro de trabajo y el nuevo Reglamento Europeo de Protección de Datos. Actualidad Jurídica Aranzadi, 932, 1-2. BIB 2018/9702.

Camos Victoria, I. (2017). El uso de cámaras video vigilancia en el centro de trabajo y el despido de un trabajador por conducta inapropiada a partir de las grabaciones realizadas. SJS núm. 2 de Sevilla, de 26 de febrero de 2016 (AS 2016, 580). Nueva Revista Española de Derecho del Trabajo, 194, 1-4.

Casino Rubio, M. (2013). Cámaras de seguridad y control de las obligaciones laborales (a propósito de la STC 29/2013, de 11 de febrero). Abogacía española [blog], 20-32013. Disponible en: https://bit.ly/2p59Bse.

Committee of Ministers EU. (2015). Recommendation CM/Rec(2015)5 to member States on the processing of personal data in the context of employment. Adopted on 1 April 2015 at the 1224th meeting of the Ministers' Deputies. Disponible en: https://bit.ly/2N69gUJ.

De las Heras Muñoz, M. (2013). El impacto de las nuevas tecnologías sobre el derecho fundamental a la intimidad. En G. M. Teruel et al. (dirs.). Desafios para los derechos de la persona ante el siglo XXI: Internet y nuevas tecnologías (pp. 115-125). Cizur Menor (Navarra): Thomson Reuters-Aranzadi.

De Vries, K. (2018). Right to respect for private and family life. En Van Dijk, P. et al. (eds.). Theory and Practice of the European Convention on Human Rights. Cambridge: Intersentia.

Desdentado Bonete, A. y Muñoz Ruíz, A. B. (2010). El control de la prestación del trabajador a través de las nuevas tecnologías: un estudio sobre la videovigilancia en la doctrina judicial. Justicia Laboral: Revista de Derecho del Trabajo y de la Seguridad Social, (44), 13-72.

Falguera Baró, M. A. (2016). Nuevas tecnologías y trabajo (II): perspectiva constitucional. Trabajo y Derecho, 21, 1-23, La Ley 6522/2016.

García González, R. y Pastor Merchante, J. (2016). Límites a la necesaria flexibilización de los derechos a la intimidad y al secreto de las comunicaciones en el ámbito laboral: una reflexión tras la sentencia del TEDH de 12 de enero de 2016 en el caso Barbulescu. Diario La Ley, 8715, Sección Tribuna, 4-3-2016. 
García Herrero, J. (2018). Videovigilancia y RGPD (II). Ocho preguntas con respuesta —control laboral y más_- Jorge García Herrero [blog], 23-4-2018. Disponible en: https://bit.ly/2NHw9xd.

González Galán, E. (2008). Percepción y uso de espacios públicos madrileños [tesis doctoral inédita]. Universidad Complutense de Madrid.

González González, C. (2016). Control empresarial de la actividad laboral, videovigilancia y deber informativo. A propósito de la STC de 3 de marzo de 2016. Revista Aranzadi Doctrinal, 5, 1-9.

Goñi Sein, J. L. (2007). La videovigilancia empresarial y la protección de datos personales. Cizur Menor (Navarra): Thomson-Civitas.

Grabenwarter, Ch. (2014). European Convention on Human Rights. Commentary. München: C. H. Beck.

Gude Fernández, A. (2014). La videovigilancia en el ámbito laboral y el derecho a la intimidad. Revista Aranzadi de Derecho y Nuevas Tecnologías, 35, 1-13.

Harris et al. (2014). Law of the European Convention on Human Rights. 3. ${ }^{\text {a }}$ ed. Oxford: Oxford University Press.

Ivanišević, B. (2018). Distinction between privacy and data protection in ECtHR's Montenegro case. BDK Advocati [blog], 13-2-2018. Disponible en: https://bit.ly/ 2BW116m.

Kilkelly, U. (2001). The right to respect for private and family life. A guide to the implementation of Article 8 of the European Convention on Human Rights. Human rights handbooks, 1. Disponible en: https://rm.coe.int/168007ff47.

Mayor Gómez, R. (2016). Comentarios a la Sentencia del Tribunal Constitucional de 3 de marzo de 2016: grabación de imágenes de trabajadores sin obtener su consentimiento previo. Gabilex, 5, 1-9.

Mercader Uguina, J. (2002). Derecho del trabajo. Nuevas tecnologías y sociedad de la información. Valladolid: Lex Nova.

Miró Morros, D. (2014). El uso de video vigilancia en el ámbito laboral. Actualidad Jurídica Aranzadi, 879, 1-3 (BIB 2014/507).

Navalpotro Ballesteros, T. (2007). Los derechos individuales frente a la videovigilancia pública. Una necesaria mirada retrospectiva a la sentencia Peck del Tribunal Europeo de Derechos Humanos. Revista Española de Derecho Administrativo, 135, 1-13.

Ollero Tassada, A. (2015). La protección de la vida privada en la jurisprudencia del Tribunal de Estrasburgo. Conclusiones al XXII Seminario del Capítulo Jurídico de AEDOS. Disponible en: https://bit.ly/2xaxeDl.

Preciado Doménech, C. H. (2017). Comentario de urgencia a la STEDH de 05 de septiembre de 2017. Caso Barbulescu contra Rumanía (Gran Sala). Recuperando la dignidad en el trabajo. Jurisdicción Social [blog], 5-9-2017. Disponible en: https:// bit.ly/2xcG1F1.

Rebollo Delgado, L. (s. f.). Vida privada y protección de datos: un acercamiento a la regulación internacional europea y española. Biblioteca Jurídica Virtual del Instituto de Investigaciones Jurídicas de la UNAM, 263-318. Disponible en: https://archivos. juridicas.unam.mx/www/bjv/libros/6/2758/10.pdf 
Roagna, I. (2012). Protecting the right to respect for private and family life under the European Convention on Human Rights. Council of Europe human rights handbooks. Estrasburgo: Consejo de Europa. Disponible en: https://bit.ly/2x7eCnG.

Rodríguez Escanciano, S. (2016). Posibilidades y límites en el uso de cámaras de videovigilancia dentro de la empresa. A propósito de la sentencia del Tribunal Constitucional de 3 de marzo de 2016. Diario La Ley, 8747, Sección Tribuna, 22-4-2016.

Rojo Torrecilla, E. (2017). ¿Puede vulnerar la vida privada de un profesor universitario la grabación de sus clases en un anfiteatro de la Universidad donde presta ordinariamente sus servicios? Sobre la sentencia del Tribunal Europeo de Derechos Humanos de 28 de noviembre de 2017. El blog de Eduardo Rojo [blog], 2-12-2017. Disponible en: https://bit.ly/2AkjV6I.

De Salas Murillo, S. (2017). Sobre el alcance del ámbito de la protección de la vida privada y familiar en la jurisprudencia de Estrasburgo. Revista Boliviana de Derecho, 23, 194-207.

Schabas, W. (2015). The European Convention on Human Rights. A Commentary. Oxford: Oxford University Press.

Schneider, H. A. (2009). Katz vs. United States: The Untold Story. McGeorge Law Review, 40, 13-23. Disponible en: https://bit.ly/2CPo5X9.

Talens Visconti, E. E. (2013). Videovigilancia mediante cámaras fijas y protección de datos en el ámbito laboral. Comentario a la sentencia del Tribunal Constitucional 29/2013, de 11 de febrero de 2013. Revista Aranzadi de Derecho y Nuevas Tecnologias, 33, 1-4.

Winn, P. (2008). Katz and the Origins or the 'Reasonable Expectation of Privacy' Test. McGeorge Law Review, 40, 1-13. Disponible en: https://bit.ly/2Ne6f4Y. 